\title{
Mientras el tiempo sea nuestro: formas del tiempo y la memoria:
}

\author{
Por Jorge Ladino Gaitán Bayona ${ }^{1}$ \\ Universidad del Tolima
}

\begin{abstract}
A.A.V.V. (2013). Mientras el tiempo sea nuestro. Antología poética. Bogotá-Santa Marta: Ediciones Exilio, 339p.
\end{abstract}

Mientras el tiempo sea nuestro (2013) es una antología poética donde se recoge la obra de Lilia Gutiérrez Riveros (Santander, 1956), Nelson Romero Guzmán (Tolima, 1952), Winston Morales Chavarro (Huila, 1969), Hernán Vargascarreño (Santander, 1960) y Andrés Berger Kiss (Hungría, 1927). Adelantado por Ediciones Exilio, su bello diseño está disponible para los lectores tanto en pasta dura como en pasta blanca. Trescientas treinta y nueve páginas que dan cuenta de diversas relaciones con

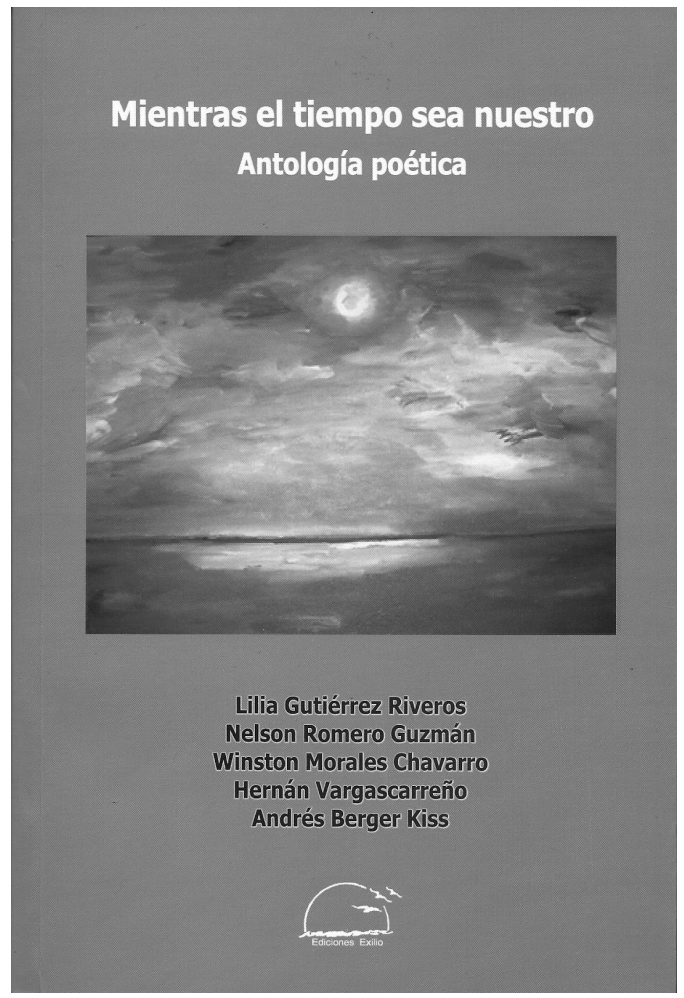
el tiempo en los cuatro autores colombianos y el escritor húngaro: el tiempo del idilio en Lilia Gutiérrez; el tiempo de la creación pictórica y poética. en Nelson Romero; el tiempo del mito, en Winston Morales; el tiempo de las digresiones -sobre el viaje, los trenes y la palabra-, en Hernán Vargascarreño; y el tiempo de la memoria, en Andrés Berger Kiss.

\footnotetext{
${ }^{1}$ Doctor en Literatura de la Universidad Católica de Chile. Licenciado en Lenguas Modernas de la Universidad del Tolima.
} 
La sección antológica de Lilia Gutiérrez Riveros se titula "Inventario 1985-2012" (21-81). Esta poeta, nacida en Macaravita, ha publicado los libros Con las alas del tiempo (1985), Carta para Nora Böring (1994), La cuarta hoja del trébol (1997), Intervalos (2005) y Pasos alquilados (2011). El hilo conductor es la experiencia del tiempo como un idilio que lleva a la poeta a ser una con la naturaleza y la divinidad. Hay una visión panteísta en sus versos que le permite vivenciar misterios en cada forma circundante. Al respecto, la poeta -ganadora de varias distinciones literarias cuyo tema es la ecologíadice en su poema "Planeta de bolsillo": "Recorro la elongación de un suspiro/ y protejo entre el bolsillo/ mi planeta de bosques y manglares/ sin ruidos en el aire/ y calma en las ciudades" (58). Enaltece en sus textos lo sagrado de la libertad y la existencia: "la vida es un hilo/ en este paréntesis de eternidad" (55). Esa eternidad la experimenta, sobre todo, cuando se abraza al mar, el gran útero inmortal.

La sección de Nelson Romero Guzmán se titula "Canción para un final" (83-143). Este poeta y ensayista, nacido en Ataco en 1952, es una de las voces más destacadas, no sólo de su departamento, sino de la lírica colombiana. No en vano su inclusión en varias antologías y sus premios recibidos, donde sobresalen el Premio Nacional de Poesía "Fernando Mejía Mejía" (1992), Premio Nacional de Poesía Universidad de Antioquia (1999) y Premio Nacional de Literatura - modalidad poesía- del Instituto Distrital de Cultura y Turismo de la Alcaldía de Bogotá (2007). Ha publicado Días sonámbulos (1988), Rumbos (1993), Surgidos de la luz (2000), Grafías del insecto (2005), La quinta del sordo (2006), Obras de mampostería (2007) y Apuntes para un cuaderno secreto (con la mexicana Kenia Cano, 2011). Desde Surgidos de la luz hasta el último de sus libros, el poeta crea su belleza morando en otras bellezas: la de la propia poesía y la de la pintura.

El arte es su casa y la fuente de sus versos. De ahí, por ejemplo, el recurso de la écfrasis (intertextualidad donde los poemas nacen como inspiración, recreación o resignificación de obras existentes en las artes visuales). La écfrasis le deja ponerse la máscara de Vincent Van Gogh, en Surgidos de la luz, la de Goya, en La quinta del sordo, y la de otros pintores, en textos líricos posteriores. Sus poemas no sólo son ricos en metáforas y figuras retóricas, sino también en propuestas estéticas donde los géneros literarios parecieran diluir sus fronteras cuando se cuentan historias desde el verso o la prosa poética. Su lírica imagina con intensidad los tiempos de la creación estética de artistas geniales y malditos a los que rodearon fantasmas, delirios, penurias y reproches. Las otras máscaras de la voz poética son las de Antonin Artaud, el Conde de Lautréamont, Jean Genet, entre otros. El 
poeta se desdobla, es otro, atormentado y visionario en la creación, tal como pareciera advertirse en el poema en prosa "Carta devuelta": "En mi íntimo ser batalla otro ser, de negros apetitos" (97).

La sección de Winston Morales Chavarro se titula "Selección de poemas" (145-206). Este escritor, nacido en Neiva en 1969, es ganador de varios galardones, entre los que vale resaltar el Concurso Nacional de Poesía "Euclides Jaramillo Arango" (2000), Premio Nacional de Poesía de la Universidad de Antioquia (2001) y Premio Nacional de Poesía Universidad Tecnológica de Bolívar (2005). En su obra poética se encuentran los libros Aniquirona (1998), De regreso a Schuaima (2001), Memorias de Alexander de Brucco (2002), Camino a Rogitama (2010) y La ciudad de las piedras que cantan (2011). Su poesía, abundante en metáforas sugestivas, se funda en los tiempos del mito. Hechos y personajes de la Biblia son astutamente recreados en Memorias de Alexander de Brucco. En otros libros el poeta busca músicas milenarias en pájaros, volcanes y aguas de lluvia, ríos y mares. Músicas que lo llevan a Schuaima, "el reino del gran más allá", donde el hombre es capaz de vivir plácido, incluso al saberse cercado por la muerte "como el rumor de un río" (159). El tiempo del mito griego se evidencia en Camino a Rogitama, donde los mismos títulos de los poemas anuncian los dioses y héroes: "Hércules", "Orfeo", "Apolo" e "Ícaro", entre otros.

La sección de Hernán Vargascarreño tiene como título "Palabra varia" (p.p. 207-268). Este escritor, nacido en Zapatoca en 1960 y conocido como traductor, tiene publicados dos atractivos libros de poesía: País íntimo (2003) y Piedra a piedra (2010). En el primero, la dedicatoria al cuento "El guardagujas", de Juan José Arreola, indica una de las obsesiones temáticas: el tren, no como símbolo del progreso, sino en su condición fantástica. La brevedad de sus textos líricos, eclosivos en sentidos y en miradas filosóficas, juega con el tema del viaje y el retorno, a partir de imágenes sobre el tren de los dioses, el tren del sueño, el tren del deseo, también trenes silenciosos, invisibles, locos y cuerdos. Hay un tren para cada ser. El tiempo de las digresiones frente a la vida, sus viajes y despedidas, es también parte de Piedra a piedra, libro donde también se da la autoconciencia sobre el poder de las palabras, su condición mágica, su relación con la divinidad y la forma en que "guardan lumbre/ para otros tiempos más aciagos" (239).

Cierra el libro la sección del escritor húngaro Andrés Berger Kiss, bajo el título "Mientras el tiempo sea nuestro", justamente el nombre que asume la antología total. Este autor, nacido en Szombathely en 1927, ha nutrido su sensibilidad estética a partir de sus viajes (los 
primeros forzosos por la condición judaica de su línea paterna). Transitó por Colombia, Estados Unidos y otras geografías. Aparte de su labor como cuentista y novelista, ha publicado los libros de poesía Voces de la tierra (1995, bilingüe, Voices from the Earth) y Mis tres patrias (2004). Esa condición judaica -donde son fundamentales la memoria, el exilio y el libro como morada- hace que su creación estética juegue con lo autobiográfico. El tiempo de la memoria no es sólo el de la evocación de la geografía colombiana y su infancia placentera en Medellín, sino también el de la rememoración dolorosa de la locura de su hermano internado en Sibaté ("Un poema para Piter") y el de los miedos y mutilaciones -de tierra, familia y afectos- a que se vieron sometidos sus padres, abuelos y allegados, que abandonaron sus hogares por las cualidades de su sangre (a diferencia de los diecisiete miembros de su familia que sucumbieron ante los nazis durante el Holocausto). Esos poemas, signados por la rememoración dolorosa, son de buena factura poética por la mesura y poder sugestivo del verso al abordar realidades crudas sin caer en tonos quejumbrosos, así como se descubre en sus poemas "En el tren del exilio" y "El día que comenzó nuestro exilio", donde se refiere que "el pueblo sin brújula ya iba por caminos inciertos" (276). 


\section{Ilustra nuestra portada César Bertel}

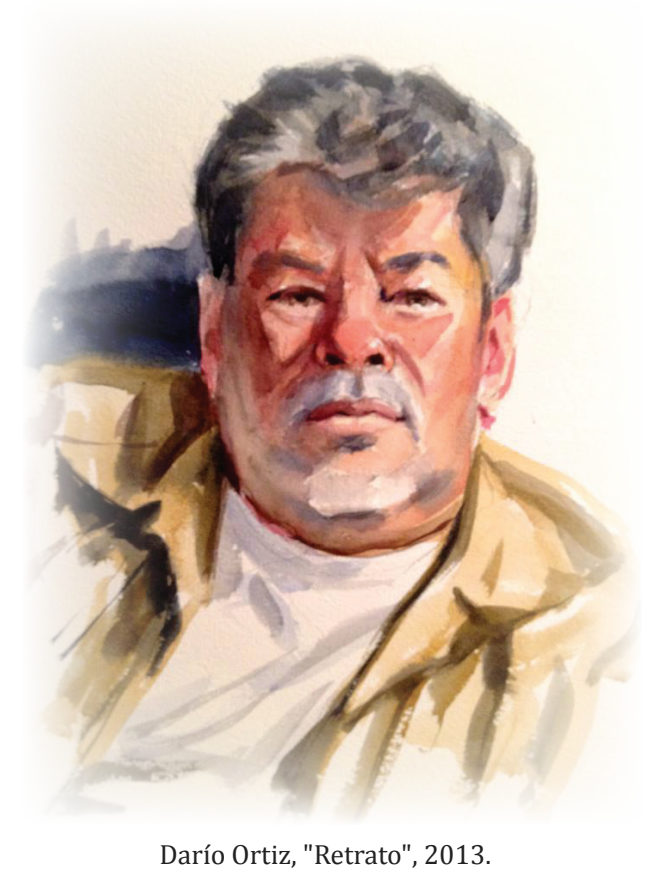

Cartagena de Indias, 1957. Pintor, dibujante y acuarelista. Algo más que perseguir el paisaje, César Bertel capta el corazón y el espíritu de la selva. No es un paisajista convencional: es un acuarelista innovador que, luego de asimilar la tradición iniciada por el colombiano Hernando Lemaitre, también de Cartagena de Indias, confrontó la tradición de esa escuela en la mirada de los asiáticos, europeos e iberoamericanos. El resultado es una acuarela que, a medida que se adentra en la experiencia visual de la selva colombiana, con sus orillas y lejanías, fronteras vegetales entre la tierra y el cielo, refleja su vocación universalista, síntesis de la mirada elusiva y sugerente de los orientales y la tradición figurativista de los occidentales. Así las sombras de luz y color de las vegetaciones profundas y las criaturas casi invisibles que surcan la naturaleza, el resplandor de los manglares que trazan con sus raíces aéreas una nueva cosmogonía en el paisaje humano: mangles con formas casi humanas, pies y huellas enormes saliendo del agua, cuerpos que ascienden a las nubes. "He vivido 15 años en la selva y tengo un registro fotográfico de 15 mil imágenes de la soledad y del silencio de la selva", ha confesado el artista. "De ese trabajo yo selecciono instantes que alimentan mi obra, pero no copio fotográficamente la selva. Capto atmósferas bajo el silencio de las hojas, en la soledad de las aguas".

\section{Gustavo Tatis Guerra}


